\title{
DEVELOPMENT OF METHODS TO INCREASE THE EFFICIENCY OF RAILWAY MAINTENANCE
}

\author{
Oleksandr Patlasov ${ }^{1}$, Yelyzaveta Fedorenko ${ }^{2}$, Denys Shulha ${ }^{3}$ \\ ${ }^{1}$ Department of Railway track and Track facilities, Dnipro National University of Railway Transport named after academician V. Lazary- \\ an, Dnipro, Ukraine \\ rapunzeeelliza@gmail.com \\ ORCID: https://orcid.org/0000-0003-2081-5648 \\ ${ }^{2}$ Department of Railway track and Track facilities, Dnipro National University of Railway Transport named after academician V. Lazary- \\ an, Dnipro, Ukraine \\ rapunzeeelliza@gmail.com \\ ORCID: https://orcid.org/0000-0002-7518-9106 \\ ${ }^{3}$ Department of Railway track and Track facilities, Dnipro National University of Railway Transport named after academician V. Lazary- \\ an, Dnipro, Ukraine \\ rapunzeeelliza@gmail.com \\ ORCID: https://orcid.org/0000-0002-9534-5241
}

\section{ABSTRACT}

Object of research: technology of track maintenance optimization.

Solved problem: In the development of decisions to optimize the decision-making system in the content of the upper structure of the track used methods of control theory, systems analysis, methodology of optimal control.

Main scientific results: An analysis of the degrees of research on improving the efficiency of the technical management of railways showed that there was no systematic approach and that existing developments in the organization, in particular the relative optimization, Separate track repair standards or take into account parameter models, process requirements and conditions.

Area of practical use of research results: industrial enterprises, railway stations.

Providing the stable support of the railway, sustainable and rhythmic operation of railway traffic is ensured. About 7.3 thousand $\mathrm{km}$ are exploited in the ferrous metallurgy of Ukraine. More than $70 \%$ of routes are up to $500 \mathrm{~km}$ long and belong to a large company. Consequently, an important task is to maintain the technical state of railways at the production demands level.

Innovative technological product: combined transportations that can interact with similar networks of foreign countries.

Scope of application of innovative technological product: formation and effective functioning of railway-transport complex, improvement of tariff policy, substantiation of perspective parameters of transportation process and its technical means, creation of advanced technologies, choice of rational structure of transport network, formation of transport corridors, development of fundamentally new management systems.

\section{Introduction}

\section{1. Object of research}

The object of the research is the technology for optimizing the maintenance of railway tracks.

\section{2. Description of the problem}

Maintenance of a railway track means the production activity of enterprises and subdivisions of the railway industry, one of the main branches of railway transport, intended to ensure the technical state of the track, its installations; it ensures uninterrupted and safe movement of trains at a certain speed. This is achieved by periodic repairs and daily maintenance of the railway within the established norms and permissible indicators of the technical state of the main machinery, timely detection, and prevention of breakdowns and malfunctions, elimination of the causes of these malfunctions on the basis of systematic monitoring and review of tracks, as well as modernization and reconstruction of the railway, anthropogenic installations, earthworks etcetera. In this case, the elements of the railway track must ensure the safe and unhindered movement of the train at the speed set for this section. 
A sufficiently large amount of research has been carried out on the problems of improving and developing the track facilities of industrial railway transport. The first projects of electric railways appeared in the late XIX century. Here, first of all, it should mention the project of engineer Z. Yanov, who proposed in 1884 the construction of an electric railway line with a length of $470 \mathrm{~km}$ from St. Petersburg to Vytegry. In 1902, the first electric narrow-gauge railway Lodz-Zgerzh was built, $19.8 \mathrm{~km}$ long. Dubelir and P. Dmitrenko. In 1898, the engineer FF Batalii proposed to build an electric railway in the Crimea, the search for which was carried out under the direction of N. Garin-Mikhailovsky in 1903. However, the project at that time failed.

In the first years of the XX century, two groups of specialists were engaged in locomotives independently of each other: Professor V. Grinnevetsky and his students A. Rustling, B. Oshurkov; Professor Yu. Lomonosov with students A. Lipets and N. Dobrovolsky. In the same years, engineer Ya. Hakkel, who was involved in the construction of the first Russian airplanes, came up with the idea of creating a locomotive with electric transmission. The developed projects served as a basis for the creation of locomotives in the future.

Problems of improving the operation of the railway were carried out by V. Prokofov in the work «Influence of the intensity of road retention» [1], V. Rubkin «Optimization of ways of conducting colonial economy» [2].

At the beginning of the XX century in Ukraine appeared the first engineering developments in the field of metro construction. They belonged primarily to Lviv and Kyiv, where the population grew rapidly and urban development covered more and more neighborhoods.

\subsection{Suggested way to solve the problem}

The problem described can be solved if methods are developed to improve the efficiency of the system of technical maintenance of railway lines of industrial enterprises by optimizing planning, integrated mechanization and improvement of travel organization and computerization of management to ensure that they are ready at minimal cost.

The main objective of Section 1. Introduction is to justify the author's approach to the problem of the efficiency of the technical maintenance system of railway enterprises

The aim of the article is to elaborate the theory and develop methods to improve the efficiency of the system of technical maintenance of railway tracks of industrial enterprises on the basis of planning optimization, integrated mechanization, and organization of track works improvement and computerization of management to ensure their readiness at minimum expense.

\section{Material and methods}

When developing solutions to optimize the decision-making system in the maintenance of the superstructure of the track, the methods of control theory, system analysis, and optimal control methodology were applied. In order to develop functional and information models of track facilities management, technologies for complex systems modeling were used, as well as design automation tools (CASE technologies, EF methodologies), were developed for the design of the Automated Control Systems. And also methods of systems analysis, control theory, optimal control methodology were applied.

\section{Result}

Track management is a multifunctional complex, the main task of which is to perform all types of preventive maintenance and repairs on railways and designs to ensure stable and safe operation of railways.

The main element of the track infrastructure is the railway, a set of technical designs and devices that are used mainly for the movement of trains and are intended for the movement of trains at a fixed speed. These include superstructure (rails, turnouts, substation), rail base with mounting hardware and bedding section), roadbed, anti-deformation drainage, protective and reinforced designs for the unlined canal in the drainage strip, fixed track structures [3]. More than $50 \%$ of all capital stocks of railway transport are concentrated in it. Currently, economic costs make up more than $30 \%$ of the total costs of the company. The main aim of the track complex at the moment is to reduce production costs at maximum throughput and maximum load-carrying capacity in terms of train safety. 
In this connection, the existing track control system should be based on the advanced development based on improving the design of the track superstructure, further mechanization, and automation of works, technologies for their implementation.

Currently, priority areas of the road complex development are [4]:

- improvement of the track long-time stability in terms of the improved designs and materials use, the transition to the implementation of work with modern complexes of track-type vehicles;

- optimization of repair technologies and current maintenance of the track and bringing the annual development of machine complexes to their capacity production;

- improvement of motivation and rise in wages in process of implementation of new technologies and increase of labour productivity.

Cost reduction is directly related to the efficiency of the production formation. The use of resource-saving programs in the track economy without increasing the production engineering performance helps to achieve a significant reduction in operating and labor costs without showing the planned cost reduction of the railway transport [5].

Currently, significant savings in the road set can be achieved only through its formation through the use of more effective technical means, updating cost management methods, improving the enterprise's work and technological processes, including intensive (quality) factors to improve financial performance. The introduction of a modernized (improved) track with a longer life cycle in areas with a huge load will significantly reduce costs. Overall constitutes the purpose of the railway complex [6].

To ensure an extended working period, it is necessary to use track superstructure materials, such as world quality standards rails of such companies as "Nippon Steel" and "Voestalpine" [7].

The jointless track with rail loops of mostly unlimited length, completely boltless, including the availability of turnouts. Due to the use of a jointless track, operating costs for its maintenance, fuel, and electricity costs for locomotive traction are reduced, as well as the time between works for scheduled maintenance increases.

The safety of trains is increased by reducing the deficiencies and malfunctions of technical aids. Regardless of the high efficiency of use, there are a number of restrictions for its conclusion, given climatic conditions, horseshoe curve, unmanageable soil [8].

Dealing with a problem in the development of long-welded rails on the territory of the state may be the expansion of laying polygons, including in horseshoe curves with a radius of less than 350300 meters using railway sleepers with increased shear resistance with the replacement of crushed broken stone ballast; durable spring-loaded rail and, mainly maintenance-free, intermediate fasteners [9].

The optimal use of this type of design is possible due in order to adopt a foreign experiment and adapt it to our conditions of use.

Renewal of subsoil in high speed and heavy sections by extraction of crushed stone from denser rocks will reduce the cost of current track maintenance. A targeted increase in the bearing capacity of the main surface of the ground through the laying of base protective layers will increase the operational intervals on high-speed sections of the railway tracks [5].

Since the technical improvement of the track design increases its reliability, the number of equipment failures that require immediate repair is reduced. When carrying out overhaul maintenance, reconstruction of the track, and turnout transfers, it is necessary to use the most closed technology for considerable distances of tracks [10].

In areas with a huge cross-country ability, it is possible to use the technology of "night" repair of tracks. To reduce the cost of routine maintenance of the track, it is necessary to put into operation new types of capital stocks [7].

Renewal of the increase way and diagnostic methods will help increase productivity and increase the economic efficiency of the track complex [11]. In connection with the subsequent changes in the technical and technological properties of railway diagnostics, it is necessary to change their quantitative indicator within the distance between the tracks and the cost of their use while ensuring the maximum safety indicator of the transport process [12].

When developing a new methodology for managing costs as a result of technological change in the travel economy, several important factors should be considered [13]:

- track maintenance cost accounting factor;

- coefficient of delay and decrease in the regional speed of train movement during performance of the works. 
The new cost management system for the road complex should be based on the use of information and resource-saving technologies. A mandatory requirement for the correct reflection of expenses is the development of a new classifier of expenses that corresponds to the management objective [2].

In connection with the new method of railway complex management, it is necessary to revise and improve the existing standards for operating costs management: norms of consumption of labour power with the current maintenance of the track and fixed track structures; consumption rates of materials and goods for the current maintenance of the track, planned preventive corrections, repair of the track and other track machinery in particular [3].

Also, the following correction data need to be included in them [14]:

1. Indicator of the railway section rate of usage - into the calculating the norms of labour and material costs.

2. Need to take deterioration of track to a greater extent into account.

3. It is necessary to improve technological standards in connection with the introduction of modernized control systems.

Currently, we are in a state where it is important to have time to absorb the newly emerging innovative technologies, which means that we need tools to quickly and efficiently change the regulatory documents for new technologies and pay special attention to the development of high-tech corporate culture [15].

In the process of functioning, the track designs are susceptible to external influences under the influence of the rolling stock of vehicles, accompanying factors of the transport systems operation (for example, traction flow on electrified sections of railway transport, etc.), natural and climatic factors, the state of the track designs at each moment of time $(t)$ can be characterized by the parametric equation of operability $P_{c}$ (target system $Z$ that is characterized by relations (1)) [16]:

$$
P_{c(t)}=f\left|S_{K C}(t), G_{K C}(t), W(t)\right|=Z(t)
$$

where $S_{K C}(t)$ - characteristics of the track design, its physical and mechanical parameters; $G_{K C}(t)$ - geometrical parameters of support elements of the track design; $W(t)$ - influence of the rolling stock of vehicles on the track design.

The analysis of this function shows that in the process of operation, the rolling stock has a more significant effect on the state of the track design [17].

Fig. 1 shows a block diagram of studies of the track maintenance system [10].

Let's consider the optimization method for track superstructure maintenance using the service life cost theory.

The most effective way to manage the condition of objects is to optimize the service life cost. For calculations, it would make sense to take the period from one overhaul maintenance (reconstruction) to the next one as the cost of the service life of the track superstructure [12]. The total cost of the service life of the track superstructure $S_{s l t}$ can be represented as the sum for the costs of the track repair work, its current maintenance, and subsequent disposal of the track superstructure in accordance with the methods $[4,18,19]$, taking into account the return cost of materials and costs in other farms associated with the condition of the track (provision of "windows", speed limits for the traction of trains and the repair of rolling stock) herewith. The optimal condition is the condition of the minimum service life cost related to the cycle duration $\mathrm{t}$ :

$$
\frac{S_{s l t}}{t}=\min , \mathrm{UAH} / \mathrm{h}
$$

The principle of the solution can be shown by an example (Fig. 2).

Broken lines show the accumulation of costs for each option over many years, straight lines connecting the beginning and end of the period increasing the value of the service life [20].

Lines inclination angle connecting the end points of the cycle corresponds to the annual cost for the maintenance and repair. The best option is the one that has a minimum service life cost of one year. In the given example, this is option No. 1. 


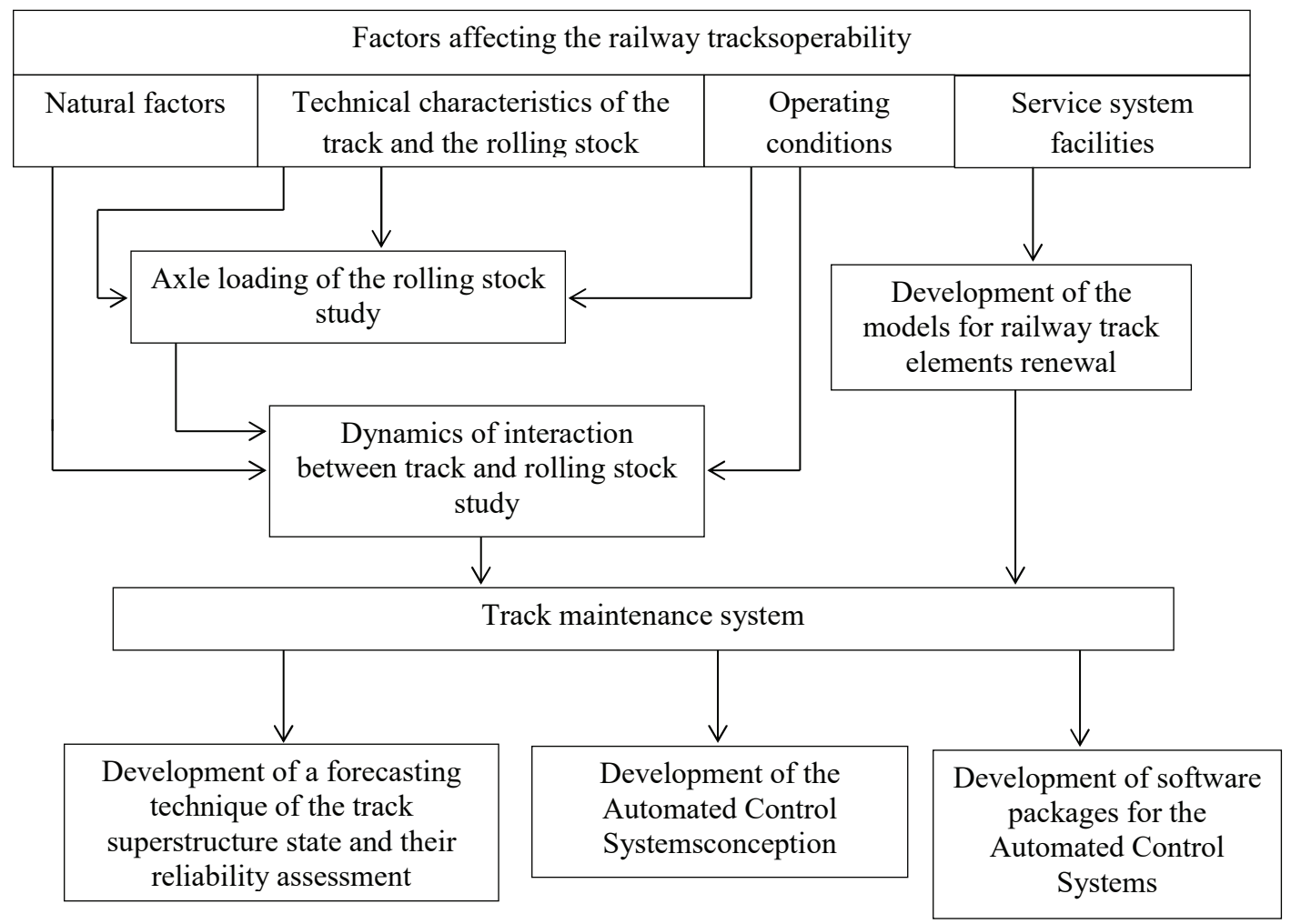

Fig. 1.Structural diagram of the track maintenance system

The next step in the article writing will be to consider a universal model of the track superstructure [11].

The classical model of the increase of the number of malfunction in use consists of three periods: part-time work, regular operation, and deterioration of the object [5].

It is considered that when the maximum breakdown level is reached, repairs should be made [21].

But several factors will make it possible to cancel the type of this dependence for the railway from the classical one [11]:

1) end of the number of elements included in the contour design. The failure rate and the number of chipped tracks have a certain meaning (for example, they can't damage 80 defective rails per $1 \mathrm{~km}$ at a length of $25 \mathrm{~m}$ );

2) level and quality of the current maintenance. By spending more limits on the current maintenance, the defect rate can stabilize and even decrease. But from a low defect level, it is possible to make a track that does not require repair. Perhaps, it would make sense to repair the track than spend money on its current maintenance, in order to solve the problems of the maintenance of the railway track optimization, a technical and economic model of its operation during the service life has been developed [22]. It is based on the use of Weibull distribution laws to describe the conduct of the random variables. This model takes into account the increase in the volume of faults and the process of restoration of the track superstructure, identifies four levels for the operation of the route [9]:

1) breaking in (stabilization) after the repair, when the intensity of the formation of defects and deviations from the standards of maintenance according to the hyperbolic law decreases;

2) normal operation, which contributes to the intensity of defect formation and stabilizes at a low-level corresponding to the flow of random malfunctions;

3) deterioration of the track state when the intensity of the formation of defects and deformations increases and the volume of the current maintenance works increases at the same time;

4) possible stage of the track state stabilization in case of an increase in the volume of the planned preventive maintenance of the current state. The condition of the track depends on the ratio of the intensity of the increase in the volumes of deviations and the amount of work of the current maintenance of the track and can both deteriorate and stabilize and even improve with high costs for current maintenance. 


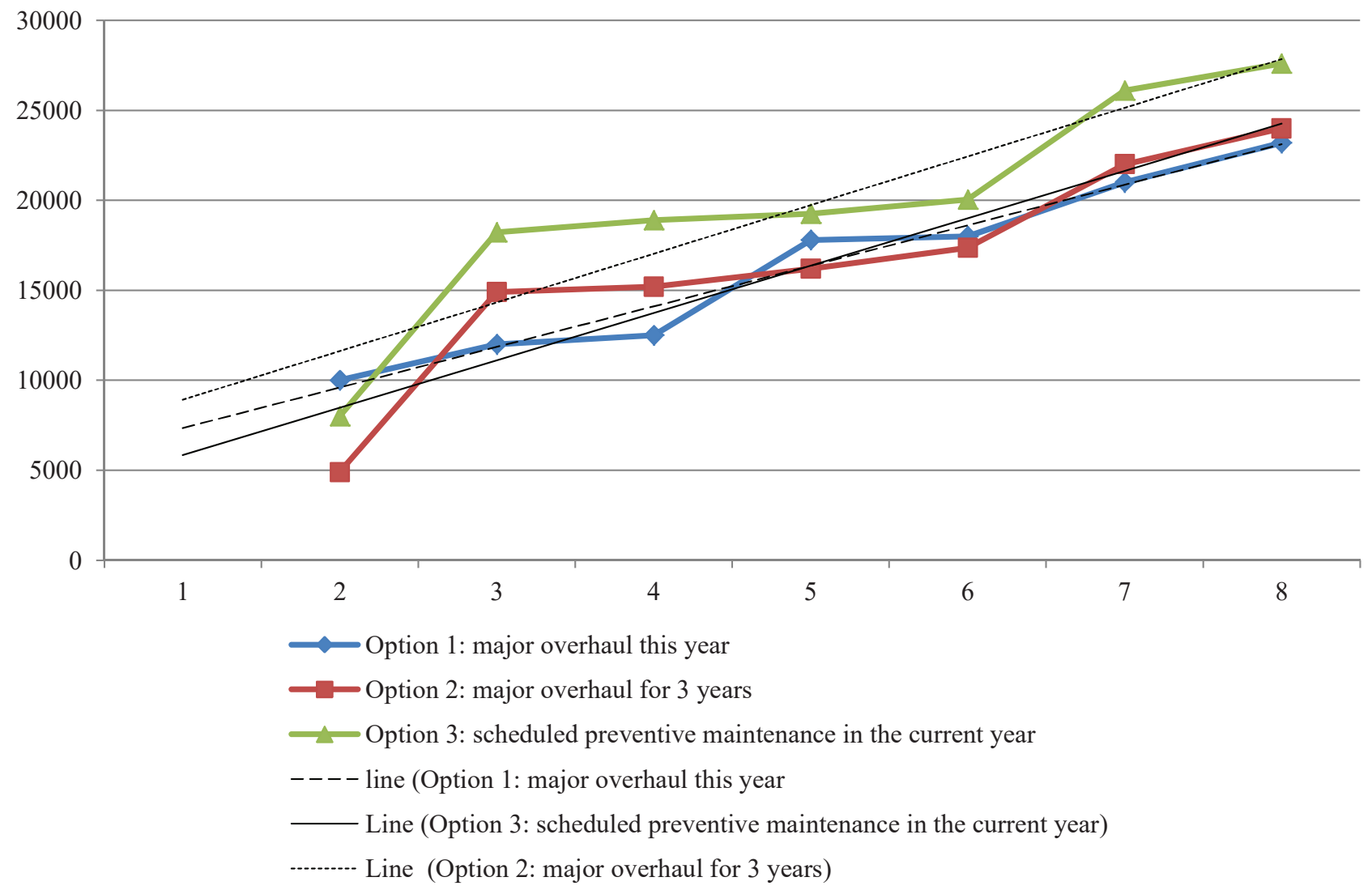

Fig. 2.Problem of service life cost optimization solving for several options of reassignment of repairs to years

The same dependencies can describe changes in the intensity of not only failures and malfunctions, but also the scope of work, as well as the cost for the current maintenance of the track between the repairs [23].

Statistical processing of the track state indicators on the railway network confirmed the type of this dependence [24]. Moreover, the lower the load voltage on the track, the earlier (with the development of tonnage) the period of track stabilization begins at the same level, and in inactive areas, it can last for decades.

Further, let's consider the determination of the influence of various factors on the efficiency of the track [2].

Previously, factors were classified according to their impact on railway works and combined into the following groups of factors [14]:

- operational (size, speed, and mode of movement, type of traction loading range);

- natural (temperature regime, duration of winter, depth of snow cover, duration of frost penetration into balls and ground fins);

- structural (material, type, and quality of superstructure elements, state of the ground, railway plan, and profile);

- high-quality repair service and constant railway maintenance.

Some factors affect the maximum operating tonnage that can be obtained by the superstructure construction, while others affect the service life in years [26]. If traffic-dependent factors prevail, the service life and frequency of repairs are limited by a certain operating time (maximum technical resource). Under the influence of natural factors, the service life is limited to a certain number of years of operation.

To study the influence of various factors on the indicators of the technical state of the railways, a statistical analysis of technological databases of technical means of the Automated Control Systems on the railway network is carried out. The road was divided into sections with 
the same design and operating conditions. During conditional operation, zones with different features are selected [1]:

- load intensity (track groups);

- duration of the winter period;

- plan and profile characteristics.

Sections with the same track designs that differ were also identified by the [27]:

- type and quality of rails (P50, P65, P75, heat-treated and wet, new and repositioned);

- subrail base (wood, reinforced concrete);

- stone bedding material (crushed stone, asbestos, etc.);

- types of fastening (ДО (DO), КД (KD), АРС (ARS), КБ (КВ), ЖБР (ZhBR), W-30, P-350);

Average network dependences of the following parameters of track state on tonnage and service life were built: single rail exit, single replacement of sleepers, percentage of unusable fastening, the average annual number of malfunctions detected by the geometry car for all types of deviations [28]. The parameter array for the dependences of the track state change on the tonnage operating time was obtained, including more than a million combinations. The purpose of this array is to forecast the change in the state of the track under different conditions [29].

The problem of determination of the optimal duration of the service life solving is also a necessary condition for the track maintenance optimization [9].

The expected service life is determined on the basis of the optimization calculations results such that the onset of the limiting state when further operation without major repairs along the way (modernization, reconstruction) becomes inappropriate. This will be such a cycle duration involving the total cost of the service life $S_{\text {slt }}$ referred to one year of service t, the minimum [16]:

$$
\frac{S_{s l t}}{t}=\frac{f(t)}{t}=\min .
$$

Fig. 3 shows the forecasting of track parameters on the basis of the combination of average network dependence and actual data on the state of the track for the previous period of non-network dependence - the trend of an increase in the number of malfunctions for sections with the same operating conditions and design. The minimum of the function is determined from the classical condition [30]:

The forecast for the increase in the number of malfunctions for the coming year is determined taking into account both the average network and local trends [27]:

$$
\Delta h=\Delta h_{l} \gamma+\Delta h_{\text {ave }}(1-\gamma)
$$

where $y$ - the share of taking into account the local trend, can take values from 0 to 1 and depends on the reliability degree of local data, determined by statistical calculations.

When forecasting the costs of the current maintenance work, the improvement of track condition indicators after the repair is taken into account by entering cost reduction factors. Cost reduction ratios show the ratio of the costs after and before repair [16]:

$$
K_{r e p-i}=\frac{c_{2}}{c_{1}}
$$

where $C_{2}$-costs for the maintenance work after track repair; $C_{1}$-before the repair. In the course of the work, the average network ratios of all observed parameters of the state of the track before and after the repairs were analysed and the cost reduction value for the current maintenance of the track after the repairs was determined. So, after overhaul maintenance, the cost reduction factor $K_{\text {rep }}$ is 0.430; after the heavy one $-0.490-0.610$ (depending on the scope of work and the depth of cleaning); after the planned preventive one -0.732 .

And finally, let's consider the methodology for the track work plans optimization through the determination of the residual life and the use of track state indices [19]. 


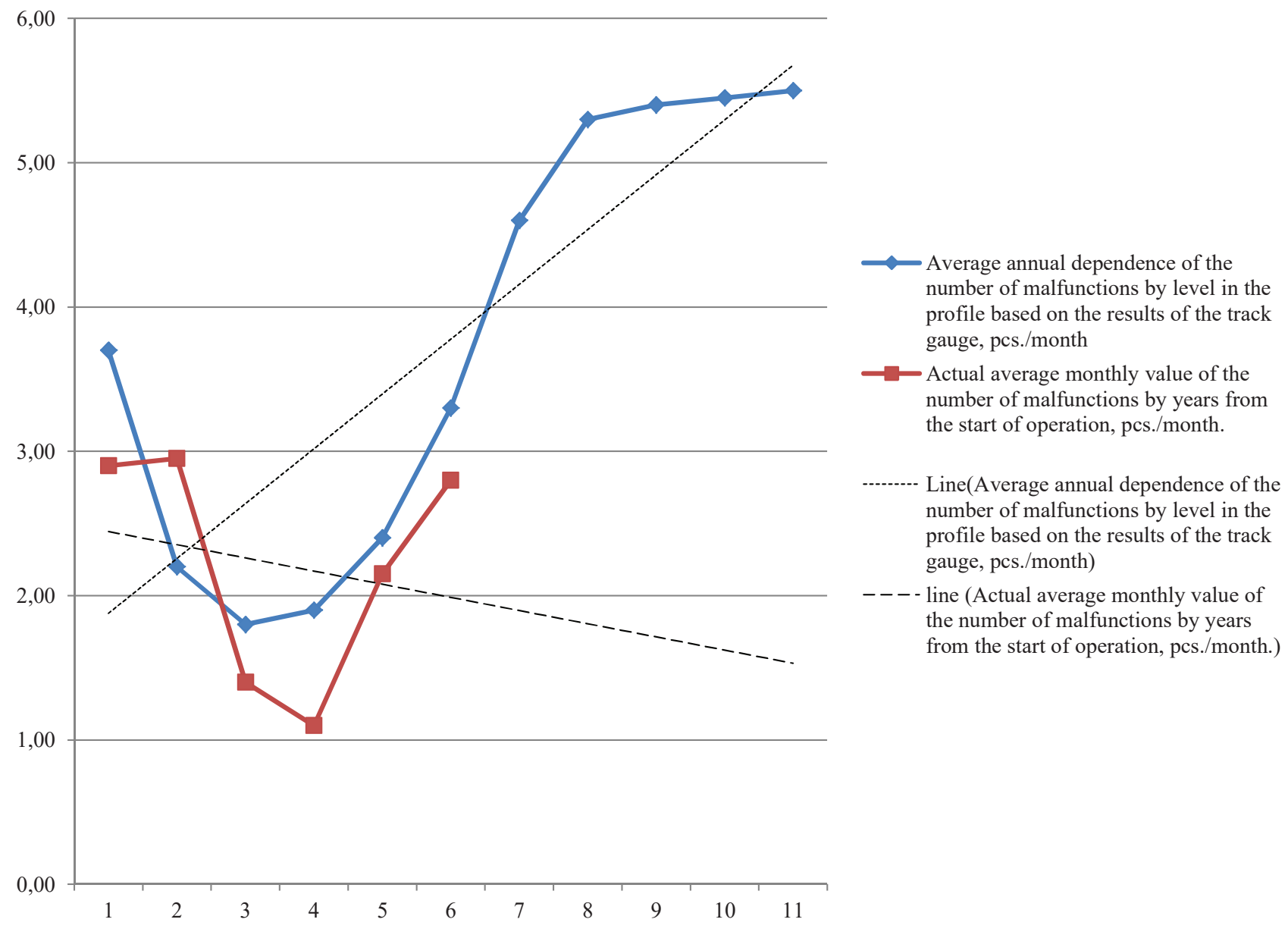

Fig. 3. Forecasting of track state parameters on the basis of the combination of average network dependence and actual data on the state of the track for the previous period of non-network dependence - the trend of an increase in the number of malfunctions for sections with the same operating conditions and design

When forecasting the technical state of the track, an important indicator is the so-called residual resource. In accordance with the terminology adopted by GOST State Standard, the residual life of an object is the cumulative operating time from the moment of monitoring of its state to the transition to the limiting state at which its further operation is unacceptable or inappropriate $[4,5]$. Thus, the calculation of the residual life should be based on calculations of the reliability of the financial viability of further operation along the way.

The residual life can be expressed in the operating time of tonnage (in areas with high load intensity), in the service life in years (in low-activity areas), or as a percentage of the residual life.[14].

Structural features of a railway track in comparison with an ideal technical object is that the track is a multi-element design, therefore, the reliability indicators of the track compared to an ideal technical object is that the track is a multi-element design, therefore the reliability indicators of the track are described by complex functions depending on the state of each element.

Construction materials of the track unloaded on tracks and stations or prepared for loading, are located on the track or the roadbeds, depending on the size of the buildings approach.

Stone bedding unloaded for the track works can be located between the tracks or on the roadbed.

The rails are located both inside the rails and at the ends of the sleepers. The distance between the nearest lateral edges of the working rail tops and, besides, if they are inside the track, must be at least $500 \mathrm{~mm}$, and when the rails are re-placed outside the track, at least $150 \mathrm{~mm}$. The rails outside are set at a minimum of $300 \mathrm{~mm}$. The distance from the edge of the sole of the rail prepared for laying to the end of the sleeper must be at least $50 \mathrm{~mm}$. The collecting bars enclosed in 
the rail runner must not be more than $50 \mathrm{~mm}$ higher than the height of the working rails and must be fixed with the working rails at the ends of the sleepers.

In the process of operation, various changes in the position of the track are possible, both in the profile and in the plan, as well as the position of designs and facilities along the track and near the railway. Often such changes lead to a violation of the overall dimensions. The operation of designs with deviations from the size requirements does not ensure the safe movement of trains and the personal safety of the workers.

The measurement of distances from the axis of the track to designs, as well as between the axes of the track is carried out by conventional measuring instruments and tools: racks, tape measures, levels, gauges. There is also a special gauge consisting of two guides, one of which is movable. Using this gauge, a worker can measure the distances from the track walking shoe axis to platforms, poles, masts, signals, and other designs with the distance from the track walking shoe axis of up to $3700 \mathrm{~mm}$ and the track walking shoe distance width when racing with a size of $4462 \mathrm{~mm}$ [16].

To select a design model of the track superstructure, let's examine a given section of the track, for example, Lvov-Stryi direction. This is a double-track, electrified, equipped with an automatic signalling section with a length of $13 \mathrm{~km}$ with a track load intensity of 19 million km gross/ $\mathrm{km}$ per year. It is serviced by an electric locomotive ВЛ10 (VL10), with a speed of freight trains of $70 \mathrm{~km} / \mathrm{h}$ and passenger trains of $100 \mathrm{~km} / \mathrm{h}$. The section has a continuous welded railway track on crushed stone bedding with an average thickness of crushed stone bedding of $30 \mathrm{~cm}$, reinforced concrete sleepers of ШC-1 (ShS-1) type with КБ 65 (KB 65) tying. The diagram of the sleepers is $1600 \mathrm{pcs} / \mathrm{km}$. The type of rails is P65, $800 \mathrm{~m}$ long. Due to the fact that the tonnage passed through this section is 300 million tons gross $/ \mathrm{km}$, but in the future, it will be 600 million tons gross $/ \mathrm{km}$ and the number of unsuitable fastenings is more than $25 \%$ and unsuitable sleepers $20 \%$ let's introduce overhaul of the track in accordance with (Table 1).

The selection of the superstructure design is determined in such a way that the superstructure design depends on the track category. The category of the track depends on the load intensity and the established speeds of movement of passenger and freight trains on the section and is determined following the Table 1.

Table 1

Track categories for the design model of the superstructure of the track selection

\begin{tabular}{ccccc}
\hline Load intensity million tons $\mathbf{k m}$ & \multicolumn{4}{c}{ Maximum set speed of passenger/freight trains on the section, $\mathbf{~ k m} / \mathbf{h}$} \\
\cline { 2 - 5 } gross in $\mathbf{k m}$ per year & $\mathbf{> 1 4 0}-\mathbf{1 6 0} / \mathbf{8 0}-\mathbf{1 2 0}$ & $\mathbf{> 1 2 0}-\mathbf{1 4 0} />\mathbf{8 0}-\mathbf{1 2 0}$ & $\mathbf{> 8 0}-\mathbf{1 2 0} />\mathbf{6 0}-\mathbf{8 0}$ & $\mathbf{8 0}$ and less/60 and less \\
\hline 80 and more & I & I & I & II \\
from 50 to 80 & I & II & II & III \\
from 30 to 50 & II & II & IV & IV \\
from 15 to 30 & II & III & V & V \\
from 5 to 15 & II & III & VI & VI \\
to 5 & II & III & VII
\end{tabular}

The analysed section of the track with a load intensity of 19 million tons gross $\mathrm{km} / \mathrm{km}$ per year, and the speed of freight and passenger trains $70 / 100 \mathrm{~km} / \mathrm{h}$ rates as the track category IV.

Depending on the track category according to the normative characteristics, let's select the main characteristic of the superstructure of the track ВБК (VBK); continuous welded railway track from rails of type P65, UIC60 of the new group I, class 1, and used rails of the types P65, UIC60 of Group I of validity; fastenings and sleepers are new or used rails in combination with new ones. The diagram of the sleepers is the same as on the tracks category I; crushed stone bedding, the thickness of the layer of new or cleaned bedding under the sleepers is at least $30 \mathrm{~cm}$.

The economic efficiency of the track design under the given operational and climatic conditions, its state, and resistance to various influences make it possible to determine the stressed-deformed state, degree of firmness, and stability of the track and its component elements.

Under the strength practical calculations of the track, the following prerequisites were taken to determine the stresses in the rail:

- rail is considered as an inseparable, weightless girder without an ultimate length of the uniform cross-section on a solid elastic cushion, which is under the action of the vertical forces; 
- it is assumed that the wheels do not detach from the rails during movement and do not have an impact action;

- vertical forces from the track are considered to be applied along the rail axial of symmetry;

- influence of the horizontal forces and eccentric application of vertical forces are taken into account using the empirical coefficient;

- dead load of the superstructure is not taken into account;

- vertical forces are calculated as dynamic, and the stress in the superstructure elements is defined as static, opposed to them;

- linear dependence between the forces acting on the rail and its deformations is assumed;

- two-way subgrade reaction is assumed, while in fact there is only a bottom-up reaction; rails are calculated only for normal stresses, local ones, including contact stresses, are not taken into account;

- it is assumed that the level of normal bending stresses to some extent characterizes the level of local stresses arising during the passage of wheels.

In addition, conventional gauges and special tools measure the oversized cargo after it has been placed on the rolling stock. Measurements are made with critical points that determine the oversize of the charge.

\section{Discussion}

Methods of the railway track superstructure maintenance system optimization on the basis of attainment of the minimum service life cost are considered and analysed. It was concluded that the decision on the design, maintenance, and repair of railways should be made on the basis of the analysis of their impact on the service life cost and forecasting costs for the future based on the general regularities of the railways and the history of changes development.

Reliability of the results obtained in the study and writing of the article, as well as the adequacy of the models developed are confirmed by the processing of the results of operational observations and control calculations of changes in the technical condition of the track superstructure at the sites of the landfill over several

The system and reception of the planning of the technical condition of the track and the cost of its maintenance in combination with determination of average laws of the network of intensity of deviations from the standards of content and faults for areas with different conditions of use and superstructure is created design.

It is not possible to construct a feasibility study of changes in the technical condition of the superstructure over the life cycle using probability methods and planning algorithms.

Based on the minimization of life-cycle costs, taking into account history, is used to plan changes in the technical condition of the superstructure and the costs of track maintenance and repair, it is necessary to create a system for increasing the efficiency of track content.

Theoretically, the model of the planned resource of the upper track system with the combined effect of operational and climatic factors is justified.

Research limitations: theoretical issues of complex mechanization of the track are still unsettled. There is no concept of creating an automated control system as a basis for improving the management of the railway control system. Analysis of the degree of research to improve the efficiency of technical control of railways showed that there is no systematic approach and existing developments in the organization, optimization, individual standards of track repair or parameter models, technological requirements, and operating conditions, in particular, are taken into account. There are no methods for track diagnostics, creation, and optimization of an integrated plan of repair and track works taking into account the state of the tracks, as well as operational planning and management of their implementation.

Thus, for further adaptation of Ukrainian railways to the trans-European railway network necessary: to develop state measures regulatory support international activities; harmonize regulatory framework in the field rail transport in accordance with international legal norms; to provide technical and technological convergence of the mobile warehouse and transport network of Ukraine with European transport system; bring technical, technological and environmental standards with European ones; bring in line with European ones standards by upgrading and reconstruction of the main routes that can be included in the pan-European transport system; de- 
velop the system railway information support industries based on modern information technologies. To solve all these problems requires coordination of actions of all structures that provide formation and effective use of transport corridors. And here it is also necessary to strengthen the regulatory role states.

\section{Conclusion}

Summarizing the above experiments, it is possible to draw the following conclusions:

1. The existing system of assignment of repair works on the missed tonnage incompletely characterizes the level of influence of a rolling stock on a track.

2. The assessment of the actual condition of the track should be carried out not on the basis of single indicators, but on the basis of the dynamics of the processes obtained as a result of monitoring.

3. The track maintenance system must be flexibly adapted to changing conditions, ensuring operational stability throughout the life cycle.

4. An effective means of extending the life cycle of the track is to improve the quality of track repair work.

Therefore, for the further development of the track economy it is necessary to solve a number of such tasks:

- increase in terms of inter-repair periods;

- increase in service life of track elements and artificial structures;

- creation of sections of track on which trains with high speeds and with significant axial load could move for a long time;

- reducing the level of dangerous events on the tracks;

- elimination of the emergency railway network;

- reduction of environmental pollution.

Today, the general condition of the track economy does not sufficiently meet the current requirements for the operation of Ukrainian railways, including their integration into the system of international transport and compliance with EU requirements in this area of management.

Thus, in Ukraine, the track economy needs to be renewed not only in terms of its logistics, but also in turn to promote rapid improvement in the field of transportation and improve the development of the domestic transport sector in the implementation of EU standards.

\section{References}

[1] Prokhorov, V. M. (2000). Vliyanie intensivnosti rasstroystva puti na ego tekuschee soderzhanie. Moscow: Inteks, 57-61.

[2] Rybkin, V. V. (1999). Optimizaciya sistemy vedeniya putevogo khozyaistva v novykh usloviyakh ehkspluatacii zheleznykh dorog Ukrainy. Dnepropetrovsk, 36. Available at: http:/disser.com.ua/optymyzatsyja-systemy-vedenyja-putevoho-khozjajstva-v-novykh-uslovyjakh-ehkspluatatsyy.html Last accessed: 04.01.2021

[3] Ivanchina, O. V. (2006). Technical and economic assessment of duration of traveling repair work. Byulleten transportnoi informacii, 10 (136), 18-20. Available at: https://elibrary.ru/item.asp?id=18869429

[4] Osnovy vedennia koliinoho hospodarstva. Available at: https://dl.kpt.sumdu.edu.ua/mod/book/tool/print/index.php?id= 9146\&chapterid=4568 Last accessed: 04.01 .2021

[5] Kalicheva, N. E. (2012). Obgruntuvannya docilnosti udoskonalennya organizaciinoi strukturi sistemi upravlinnya koliziinim gospodarstvom pri zaprovadzhenni shvidkisnogo rukhu na teritorii Ukraini. Visnik ekonomiki transportu i promislovosti, 39, 124-128. Available at: https://cyberleninka.ru/article/n/obgruntuvannya-dotsilnosti-udoskonalennya-organizatsiynoyi-strukturi-sistemi-upravlinnya-koliynim-gospodarstvom-pri-zaprovadzhenni Last accessed: 04.01.2021

[6] Zoeteman, A. (2001). Life cycle cost analysis for managing rail infrastructure. Concept of a decision support system for railway design and maintenance. European Journal of Transport and Infrastructure Research, 1 (4), 391-413. doi: http://doi.org/ 10.18757/ejtir.2001.1.4.3506

[7] Mashkin, O. M.; Smolii, V. A. et. al. (2015). Zaliznytsi, zaliznychni shliakhy na ukrainskykh terytoriiakh v 19-20 st. Enciklopediya istorii Ukraini. Vol. 3. Kyiv: Naukova dumka, 672. Available at: http://www.history.org.ua/?termin=Zaliznyci

[8] Kalicheva, N. E., Tikhonravov, S. M., Bilyaeva, Ya. B. (2016). Features of innovative development of track facilities of railway transport of Ukraine. Visnik ekonomiki transportu i promislovosti, 55, 68-72. Available at: https:/cyberleninka.ru/article/n/ osoblivosti-innovatsiynogo-rozvitku-koliynogo-gospodarstva-zaliznichnogo-transportu-ukrayini Last accessed: 04.01.2021

[9] Kamenskii, V. B. (2005). Sistema vedeniya putevykh rabot nuzhdaetsya v korrektirovke. Put i putevoe khozyaistvo, 3, 6-8.

[10] Polozhennia pro systemu vedennia koliinoho hospodarstva (2020). Nakaz Ministerstvo transportu ta zvyazku Ukrainy No. 807-C. 22.12.2020. Available at: http://online.budstandart.com/ua/catalog/doc-page.html?id_doc=79632 Last accessed: 04.01.2021 
[11] Railway Management System Market by Component (Solution and Services) - Global Opportunity Analysis and Industry Forecast, 2016-2023. Available at: https://www.alliedmarketresearch.com/railway-management-system-market Last accessed: 04.01.2021

[12] Orhanizatsiia remontiv kolii (2016). Available at: https://otherreferats.allbest.ru/transport/00690175_0.html Last accessed: 04.01.2021

[13] Put i putevoe khazyajstvo. Belorusskaya zheleznaya doroga. Available at: https://www.rw.by/corporate/belarusian_railway/ infrastructure/track_and_track_facilities Last accessed: 04.01.2021

[14] Programma modernizacii zheleznykh dorog Chekhii (2016). Zheleznye dorogi mira, 1. Available at: http://1430mm.ru/ czech-republic-railway/programma-modernizacii-zheleznyh-dorog-chehii Last accessed: 04.01.2021

[15] Rybkin, V. V., Patlasov, O. M., Panchenko, P. V. (2015). Eksperymentalni doslidzhennia vzaiemodii kolii ta rukhomoho skladu pry shvydkostiakh rukhu do $160 \mathrm{~km} /$ hod. Sbornik nauchnykh trudov Donetskogo instituta zheleznodorozhnogo transporta, 35, 191-197. Available at: https://cyberleninka.ru/article/n/eksperimentalni-doslidzhennya-vzaemodiyi-koliyi-ta-ruhomogo-skladu-pri-shvidkostyah-ruhu-do-160-km-god Last accessed: 04.01.2021

[16] Kalycheva, N. Ye. (2012). Napriamy vyznachennia efektyvnosti orhanizatsii robit pry modernizatsii koliinoho hospodarstva. Ekonomichnyi visnyk Donbasu, 2 (28), 125-131.

[17] Kopylov, N. (2020). Uroki zheleznykh dorog SSHA dlya Ukrainy. Available at: https://biz.censor.net/resonance/3190852/ uroki_jeleznyh_dorog_ssha_dlya_ukrainy Last accessed: 04.01.2021

[18] Kovalenko, N. I., Aimaletdinov, Kh. R. (2008). Organizaciya uchastkovoi sistemy. Put i putevoe khozyaistvo, 12, 22-23.

[19] Kurhan, M. B., Verbitskii, V. G., Kurhan, D. M. (2019). Difference research of ukrainian and european railway infrastructure. Science and Transport Progress. Bulletin of Dnipropetrovsk National University of Railway Transport, 5 (83), 52-70. doi: http://doi.org/10.15802/stp2019/184497

[20] Beltyukov, V. P. (2015). Optimizatsiya sistemy soderzhaniya zheleznodorozhnogo puti na osnovanii prognozirovaniya izmeneniya ego sostoyaniya i zatrat, svyazannykh s ego soderzhaniem. Put XXI veka. Saint Petersburg, 14-23.

[21] Organizacij remontu zaliznichnikh kolii (2017). Available at: https://otherreferats.allbest.ru/transport/00807414_0.html Last accessed: 04.01.2021

[22] Rozvytok teorii i metodiv pidvyshchennia efektyvnosti systemy tekhnichnoho utrymannia zaliznychnykh kolii promyslovykh pidpryiemstv (2014). Available at: https://otherreferats.allbest.ru/transport/00441438_0.html Last accessed: 04.01.2021

[23] Yanin, V. M. (2015). Issledovanie optimalnogo raspredeleniya remontov puti v mezhremontnyi period v svyazi s povysheniem skorosti dvizheniya gruzovykh poezdov. Saint Petersburg: LIIZHT, 126.

[24] RFID Railway Management System. Available at: https://gaorfid.com/gao-railway-management-system Last accessed: 04.01.2021

[25] Sheronova, T. N. (2008). O normakh periodichnosti remontno-putevykh rabot. Put i putevoe khozyaistvo, 10, $33-41$.

[26] Railway Management System by Solution Service, and Region - Global Forecast to 2025. Available at: https://www.marketsandmarkets.com/Market-Reports/railway-management-system-market-193193339.html Last accessed: 04.01.2021

[27] Pravila soderzhaniya i okhraneniya parovoznykh zheleznykh dorog (1883).

[28] Making the railway system work better for society. Available at: https://www.era.europa.eu Last accessed: 04.01.2021

[29] Yatskivskyi, L. Yu., Zerkalov, D. V. (2017). Zagalnii kurs transportu. Kyiv: Aristei, 458. Available at: https://www.studmed.ru/ yackvskiy-lyu-zerkalov-dv-zagalniy-kurs-transportu_0fcf0428db6.html Last accessed: 04.01.2021

[30] Canadian Pacific Railway official website. Available at: https://www.cpr.ca/en Last accessed: 04.01.2021 